\title{
Circulating endothelin-1 concentrations in patients with chronic hypoxia
}

\author{
C Ferri, C Bellini, C De Angelis, L De Siati, A Perrone, G Properzi, A Santucci
}

\begin{abstract}
Aims-To evaluate the behaviour of plasma endothelin-1 in patients with chronic hypoxia.

Methods-Fifteen male patients (mean age $52 \cdot 1 \pm 3 \cdot 1$ years) with mild chronic obstructive pulmonary disease (COPD) were studied. Twelve healthy men (mean age $48 \cdot 3 \pm 5 \cdot 4$ years) served as controls. Both patients and controls underwent standard pulmonary function tests, echocardiographic evaluation, and arterial blood gas evaluation. Blood samples for endothelin-1 assay were taken from a previously incannulated antecubital vein after 60 minutes of rest in the supine position. Endothelin-1 was measured by radioimmunoassay after extraction from plasma.
\end{abstract}

Results-Patients with chronic hypoxia had lower $\mathrm{PaO}_{2}$ values $(66 \cdot 1 \pm 6 \cdot 2 \mathrm{mmHg})$ than controls $(83.8 \pm 2.7 \mathrm{mmHg})$ but $\mathrm{PaCO}_{2}$ values were similar $(38 \cdot 1 \pm 2 \cdot 5 v$ $36 \cdot 7 \pm 3 \cdot 1 \mathrm{mmHg}$, respectively). Arterial pulmonary pressure, therefore, was higher in patients $(18.1 \pm 3.7 \mathrm{mmHg})$ than in controls $(10.4 \pm 2.7 \mathrm{mmHg})$ as were circulating endothelin-1 concentrations $(1 \cdot 22 \pm 0.36$ v $0.57 \pm 0 \cdot 1 \mathrm{pg} / \mathrm{ml})$. Furthermore, plasma endothelin-1 concentrations were negatively correlated with $\mathrm{PaO}_{2}$ and directly correlated with pulmonary pressure levels. No significant correlations were found in controls.

Conclusions-These results show a clear relation between chronic hypoxia and circulating endothelin-1 concentrations. Therefore, chronic hypoxia may be regarded as an important stimulus for endothelin-1 release and as one of the main contributors to increased vasoconstriction in the vascular pulmonary bed which often accompanies lung disease.

(f Clin Pathol 1995;48:519-524)

Keywords: Endothelin-1, hypoxia, respiratory disease, pulmonary hypertension.

Endothelin-1 is a recently discovered peptide composed of 21 amino acids and released by endothelial cells. ${ }^{12}$ Human endothelin-1 is derived from preproendothelin-1, a 212 amino acid peptide, via a 38 amino acid intermediate known as big endothelin-1. The expression of preproendothelin-1 messenger RNA (mRNA) is stimulated by vasopressor hormones such as epinephrine, angiotensin II and arginine vasopressin, ${ }^{3}$ substances generated from activated/ aggregating platelets such as transforming growth factor $\beta,{ }^{3}$ coagulation products such as thrombin, ${ }^{4}$ cytokines such as interleukin- $1,{ }^{5}$ and shear stress. ${ }^{6}$ Furthermore, substances such as nitric oxide, ${ }^{7}$ prostacyclin, ${ }^{7}$ atrial natriuretic peptide, ${ }^{8}$ and an unknown vascular smooth muscle cell derived inhibitory factor ${ }^{9}$ act as inhibitors of endothelin-1 production or secretion, or both. Because of its vasoconstrictive and mitogenic properties, endothelin-1 affects cardiovascular, pulmonary and renal function, ${ }^{1310}$ and may be involved in the development of several diseases, such as atherosclerosis, ${ }^{2}$ myocardial infarction, ${ }^{11}$ renal disease, ${ }^{310}$ and systemic ${ }^{3}$ and pulmonary hypertension. ${ }^{12}$

With regard to the possible interactions between endothelin-1 and pulmonary functions, hypoxia stimulates the release of endothelin-1 from rat resistance vessels. ${ }^{13}$ In cultured cells derived from human umbilical cord veins Kourembanas et $a l^{14}$ demonstrated that hypoxia induced upregulation of endothelin-1 gene transcription results in a four- to eightfold increase in endothelin-1 secretion. Moreover, a recent interesting study conducted in healthy men indicated that hypobaric hypoxia induced by trekking from $1200 \mathrm{~m}$ to $5000 \mathrm{~m}$ over eight days caused an increase in circulating endothelin-1 concentrations which was inversely correlated with oxygen saturation. ${ }^{15}$ Several other factors could have influenced the behaviour of plasma endothelin-1 in these subjects, including the haemodynamic and hormonal changes which usually occur following altitude acclimatisation. ${ }^{16}$ Moreover, oxygen tension in the blood was indirectly evaluated as saturated haemoglobin, by percutaneous oxymetry, the measurement of which is strongly affected by cutaneous vasoconstriction caused by total body cooling. However, the report by Giussani et $a l^{15}$ clearly suggests that hypoxia may affect plasma endothelin-1 concentrations. In this context, several studies reported a close correlation between circulating endothelin-1 and arterial pulmonary pressure. ${ }^{3712}$ Therefore, we postulated that a pathological condition associated with chronic hypoxia could be used to evaluate the influence of blood oxygen concentrations on plasma endothelin-1 concentrations, and to verify whether or not the behaviour of this peptide is related to both $\mathrm{PaO}_{2}$ and pulmonary pressure levels. To test this hypothesis, we studied male patients with chronic obstructive pulmonary disease (COPD), but without clinical, ultrasound, or biochemical evidence of atherosclerosis, metabolic abnormalities of lipid or carbohydrate metabolism, or renal function abnormalities. 


\section{Methods}

The study was approved by the Ethics Committee of the Andrea Cesalpino Foundation. All the participants gave their informed consent on entry. As several factors related to the menstrual cycle and/or menopause influence the behaviour of several hormones which regulate endothelial function, ${ }^{17}$ we decided to study male patients only.

Twenty five white men (mean age 53.9 \pm 3.8 years) with mild COPD were initially enrolled in the study. The diagnosis of COPD was based on a past history of chronic bronchitis and evidence of air flow abnormalities on standard pulmonary function tests (forced expiratory volume in one second $\left(\mathrm{FEV}_{1}\right)<80 \%$ predicted values, $\mathrm{FEV}_{1} /$ vital capacity $<80 \%$ normal values). All were outpatients aged between 40 and 60 years; had not been taking cardiac glycosides, diuretics, steroids, or theophylline in the three months before the study; did not smoke or drink; and had a body mass index between 19 and $25 \mathrm{~kg} / \mathrm{m}^{2}$; supine systolic and diastolic blood pressures below 140 and $90 \mathrm{mmHg}$, respectively; a serum creatinine concentration $<100 \mu \mathrm{mol} / \mathrm{l}$; a serum sodium concentration $>135 \mathrm{mmol} / \mathrm{l}$; microalbuminuria $<20 \mu \mathrm{g} /$ minute; absence of proteinuria; normal glucose metabolism (that is, fasting glucose concentrations $<6.0 \mathrm{mmol} / 1$ and a normal plasma glucose and insulin response to the oral glucose tolerance test $(75 \mathrm{~g})$ ); serum cholesterol concentrations between 3.7 and $5.1 \mathrm{mmol} / 1$; and serum triglyceride concentrations between 1.1 and $1.6 \mathrm{mmol} / 1$. Clinical and echo-Doppler evaluation of the neck and limb vessels excluded the presence of atherosclerotic lesions. Moreover, none of the patients had cardiac, hepatic or adrenal disease, or had significant peripheral oedema as assessed by clinical, ultrasound and laboratory tests. In particular, absence of cor pulmonale and left ventricular dysfunction was documented on clinical examination and by electrocardiography and echocardiography. Both patients and controls underwent echocardiographic examination permitting evaluation of the main morphological and functional parameters, such as pulmonary pressure, left ventricular ejection fraction and ventricular kinesis. In particular, two patients with a left ventricular ejection fraction lower than $50 \%$ and five patients in whom it was technically impossible to obtain a reliable echo-Doppler evaluation of pulmonary arterial pressure were excluded from the study.

The remaining cohort (18 patients, mean age $51.7 \pm 4.5$ years) underwent standard pulmonary function tests and analysis of arterial blood gas values. All patients had a $\mathrm{PaCO}_{2}$ $<40 \mathrm{mmHg}$, whereas $\mathrm{PaO}_{2}$ values ranged from 55 to $75 \mathrm{mmHg}$. Twelve healthy men (mean age $48 \cdot 3 \pm 5 \cdot 4$ years) served as controls. Entry criteria were identical with those for the patients.

After recruitment, to establish standard conditions, both patients and controls were placed on a normocaloric diet (about $1 \mathrm{~g} / \mathrm{kg}$ protein, $2 \mathrm{~g} / \mathrm{kg}$ carbohydrates, $0.7 \mathrm{~g} / \mathrm{kg}$ fat) for two weeks with fixed sodium and potassium intake $(120 \mathrm{mmol}$ sodium and $60 \mathrm{mmol}$ potassium daily). Sodium was given as sodium chloride. Compliance with restrictions on sodium intake was assessed by measuring 24 hour urinary sodium and chloride excretion on the last three consecutive days of each week. Patients and controls with $\mathrm{Na}^{+}$urinary excretion $<80$ or $>130 \mathrm{mmol} / 24$ hours were excluded. During this phase, three further patients were excluded from the study (all of them had a urinary sodium excretion $>140 \mathrm{mmol} / 24$ hours). The remaining cohort of 15 patients (mean age $52 \cdot 1 \pm 3 \cdot 1$ years) and 12 normal subjects constituted the study population. Patients were advised to stop using oral and/or inhaled bronchodilators for the 12 hours before the study. Participants came to the outpatient department at 0800 hours and assumed the supine position in an air conditioned room $\left(22-24^{\circ} \mathrm{C}\right)$. An antecubital vein was incannulated with a teflon catheter (Viggo-Spectramed, Helsingborg, Sweden) which was kept pervious by saline $(0.9 \% \mathrm{NaCl}$ at a rate of $10 \mathrm{ml} /$ hour $)$. After 60 minutes of rest, during which blood pressure and heart rate were constantly recorded at 10 minute intervals by an automatic sphygmomanometer (Nippon Colin, Komaki, Japan), venous blood samples for determination of osmolality and plasma endothelin-1, serum electrolyte and creatinine concentrations were taken from the pervious prepared antecubital vein. This particular procedure was chosen to avoid the influence of venepuncture and blood stasis $^{18}$ on the release of endothelin-1 from venous endothelial cells. Immediately after venous blood sampling, arterial blood samples for evaluation of blood gas levels were drawn from a brachial artery. For correlations between circulating endothelin-1 and urinary $\mathrm{Na}^{+}, \mathrm{K}^{+}$and creatinine excretion, the last 24 hour collection of each patient was used.

\section{BIOCHEMICAL TESTS}

Blood samples for the plasma endothelin-1 assay were collected into pre-chilled tubes (Becton Dickinson Vacutainer Systems, New Jersey, NJ, USA) containing EDTA-K E $_{3}(15 \%)$ and aprotinin $(500 \mathrm{KIU} / \mathrm{ml}$ blood) and promptly centrifuged at $1600 \times g$ at $0-4^{\circ} \mathrm{C}$ for 15 minutes. Plasma was pipetted into polypropylene tubes and stored at $-80^{\circ} \mathrm{C}$ until assayed (mean five days, range one to 10 days). Plasma endothelin-1 was concentrated by extraction through C18 Sep-Pak cartridges (Millipore Corporation, Marlborough, Massachusetts, USA). Sep-Pak columns were activated with $0.1 \%$ trifluoroacetic acid buffer, loaded with $2 \mathrm{ml}$ plasma and then washed with $0 \cdot 1 \%$ trifluoroacetic acid buffer. The retained material was eluted with $3 \mathrm{ml}$ of a buffer containing acetonitril $(60 \%)$ in $0.1 \%$ trifluoroacetic acid, and dried in a vacuum by a centrifugal evaporator system (Gyrovap, Howe \& Co., London UK). A commercial radioimmunoassay kit (Peninsula Laboratories, Belmont, CA, USA) was used to measure endothelin-1 concentrations in the reconstituted pellet. Cross-reactivity of the system for endothelin- 1 is $100 \%$, but is less than $7 \%$ for both endothelin- 2 and endothelin- 3 according 
to the manufacturer. Intra- and interassay coefficients of variation in our laboratory were $<10 \%$. Recovery was $80 \%$. Serum and urinary electrolytes were measured by standard laboratory methods using a flame photometer (Biotechnica Instruments, Rome, Italy). Plasma osmolality was determined as freezing point depression by an osmometer (Fiske 2400 Multi-sample Osmometer, Fiske Associates, Needham Heights, Massachusetts, USA).

\section{BLOOD GAS EXCHANGE MEASUREMENTS}

Arterial blood was collected in heparinised syringes from a brachial artery. Gas evaluations were performed by a standard laboratory blood gas analyser (ABL 510 Radiometer, Copenhagen, Denmark).

\section{BLOOD PRESSURE AND ECHOCARDIOGRAPHIC EVALUATIONS}

Systemic arterial blood pressure and heart rate were measured at 10 minute intervals using an automatic sphygmomanometer (Nippon Colin). Mean blood pressure (MBP; $\mathbf{m m H g}$ ) was evaluated using the formula:

$$
\mathrm{MBP}=\mathrm{DBP}+(\mathrm{SBP}-\mathrm{DBP})
$$

where DBP is the diastolic and SBP the systolic blood pressure.

Echocardiographic studies were performed using commercially available equipment with

Table 1 General characteristics (mean $\pm S D$ ) of the study population

\begin{tabular}{|c|c|c|}
\hline Variable & $\begin{array}{l}\text { Patients } \\
(n=15)\end{array}$ & $\begin{array}{l}\text { Controls } \\
(n=12)\end{array}$ \\
\hline $\begin{array}{l}\text { Age (years) } \\
\text { Disease duration (years) } \\
\text { Body mass index }\left(\mathrm{kg} / \mathrm{m}^{2}\right) \\
\text { SBP (mmHg) } \\
\text { DBP (mmHg) } \\
\text { MBP (mmHg) } \\
\text { Heart rate (beats/minute) } \\
\text { Serum creatinine }(\mu \mathrm{mol} / 1) \\
\text { Creatinine clearance }(\mathrm{ml} / \mathrm{s}) \\
\text { Blood urea (mmol//) } \\
\text { Serum } \mathrm{Na}^{+}(\mathrm{mmol} / \mathrm{l}) \\
\text { Serum } \mathrm{K}^{+}(\mathrm{mmol} / \mathrm{)}) \\
\text { Plasma fasting glucose }(\mathrm{mmol} / \mathrm{l}) \\
\text { Plasma fasting insulin }(\mathrm{pmol} / 1) \\
\text { Plasma osmolality }(\mathrm{mmol} / \mathrm{kg}) \\
\text { Serum cholesterol }(\mathrm{mmol} / \mathrm{l}) \\
\text { Serum triglycerides }(\mathrm{mmol} / \mathrm{l})\end{array}$ & $\begin{aligned} & 52 \cdot 1 \pm 3 \cdot 1 \\
& 4 \cdot 2 \pm 0 \cdot 2 \\
& 24 \cdot 1 \pm 0 \cdot 4 \\
& 127 \cdot 3 \pm 3 \cdot 1 \\
& 80 \cdot 1 \pm 2 \cdot 6 \\
& 95 \cdot 8 \pm 3 \cdot 0 \\
& 75 \cdot 1 \pm 1 \cdot 5 \\
& 81 \cdot 0 \pm 10 \cdot 1 \\
& 1 \cdot 6 \pm 0 \cdot 5 \\
& 10 \cdot 9 \pm 0 \cdot 9 \\
& 138 \cdot 4 \pm 3 \cdot 2 \\
& 4 \cdot 2 \pm 0.4 \\
& 5 \cdot 1 \pm 0.6 \\
& 93 \cdot 4 \pm 8 \cdot 1 \\
& 286 \cdot 3 \pm 3 \cdot 2 \\
& 4 \cdot 4 \pm 0 \cdot 2 \\
& 1 \cdot 5 \pm 0.1\end{aligned}$ & $\begin{array}{r}48 \cdot 3 \pm 5 \cdot 4 \\
22 \cdot 8 \pm 0 \cdot 3 \\
122 \cdot 9 \pm 4 \cdot 5 \\
78 \cdot 8 \pm 2 \cdot 1 \\
93 \cdot 5 \pm 2 \cdot 9 \\
71 \cdot 2 \pm 0 \cdot 9 \\
80 \cdot 5 \pm 9 \cdot 3 \\
1 \cdot 7 \pm 0 \cdot 3 \\
11 \cdot 3 \pm 1 \cdot 0 \\
139 \cdot 1 \pm 3 \cdot 4 \\
4 \cdot 5 \pm 0 \cdot 2 \\
4 \cdot 6 \pm 0 \cdot 3 \\
78 \cdot 6 \pm 9 \cdot 1 \\
285 \cdot 8 \pm 2 \cdot 9 \\
4 \cdot 2 \pm 0 \cdot 2 \\
1 \cdot 3 \pm 0 \cdot 2\end{array}$ \\
\hline
\end{tabular}

SBP, systolic blood pressure; DBP, diastolic blood pressure.

Table 2 Respiratory and cardiac parameters of the study population

\begin{tabular}{|c|c|c|}
\hline Variable & $\begin{array}{l}\text { Patients } \\
(n=15)\end{array}$ & $\begin{array}{l}\text { Controls } \\
(n=12)\end{array}$ \\
\hline $\begin{array}{l}\text { Forced vital capacity (litre) } \\
\mathrm{FEV}_{1} \text { (1/one second) } \\
\mathrm{FEV}_{1} \text { /forced vital capacity (\%) } \\
\mathrm{PaO}_{2} \text { (mmHg) } \\
\mathrm{PaCO}_{2}(\mathrm{mmHg}) \\
\mathrm{Arterial}_{\mathrm{pH}} \\
\text { Serum bicarbonates (mmol/l) } \\
\text { Respiratory rate (breaths/minute) } \\
\text { Haematocrit (\%) } \\
\text { Haemoglobin (g/l) } \\
\text { Oxygen saturation (\% saturated haemoglobin) } \\
\text { Pulmonary pressure (mmHg) } \\
\text { Left ventricular ejection fraction (\%) }\end{array}$ & $\begin{aligned} 2 \cdot 8 \pm 1 \cdot 5 \\
1.9 \pm 0 \cdot 2 \\
67 \cdot 8 \pm 3 \cdot 4 \\
66 \cdot 1 \pm 6 \cdot 2 \\
38 \cdot 1 \pm 2 \cdot 5 \\
7 \cdot 37 \pm 0 \cdot 01 \\
25 \cdot 1 \pm 2 \cdot 1 \\
16 \cdot 1 \pm 1 \cdot 5 \\
46 \cdot 1 \pm 1 \cdot 5 \\
131 \cdot 3 \pm 10 \cdot 2 \\
88 \cdot 5 \pm 4 \cdot 4 \\
18 \cdot 1 \pm 3 \cdot 7 \\
65 \cdot 6 \pm 8 \cdot 9\end{aligned}$ & 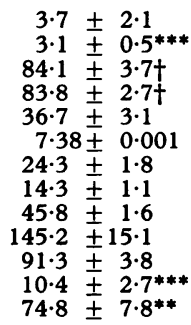 \\
\hline
\end{tabular}

$\mathrm{FEV}_{1}$, forced expiratory volume in one second.

${ }^{* *} \mathrm{p}<0.01 v$ patients with COPD; ${ }^{* * *} \mathrm{p}<0.001 v$ patients with COPD; $+\mathrm{p}<0.0005 v$ patients with COPD. left parasternal and apical approaches. Both patients and controls underwent a complete $\mathbf{M}$ mode and $B$ mode evaluation. Functioning of all cardiac valves was also investigated by colour Doppler. Conventionally, blood flow directed towards the transducer was codified in red and that directed away from the transducer in blue; a green colour (variance) represented turbulent flow. Tricuspid regurgitation was carefully detected: the transducer was manipulated to obtain the best visualisation of valvular insufficiency by colour-flow Doppler mapping and a continuous wave Doppler cursor was positioned parallel to the flow. If the angle of intersection between the Doppler cursor and tricuspid regurgitant flow was $>20^{\circ}$, attempts to detect tricuspid insufficiency were repeated from the subcostal transducer position. In some cases the subjects were asked to take a deep breath and to remain in inspiratory apnea: in this way, it was usually possible to obtain an optimal representation of tricuspid regurgitant flow and to place the Doppler cursor in position parallel to it. The same manoeuvres were then repeated using the non-imaging, high-sensitivity Pedoff transducer. In our experience, the latter transducer provides an opportunity to detect more defined Doppler envelopes and higher velocities than with combined imaging and the continuous wave Doppler probe. The maximum velocity of the signal tracing observed on at least two consecutive cardiac cycles was used to calculate the pressure gradient. Optimal signals were assumed to be orientated parallel to the direction of regurgitation and thus a flow angle correction for velocity was not used. The transtricuspid systolic pressure gradient (TSPG; in $\mathrm{mmHg}$ ) was calculated on the basis of the modified Bernoulli equation ${ }^{19}$ :

$$
\mathrm{TSPG}=4 \mathrm{~V} 2
$$

where $\mathrm{V}$ represents the peak systolic velocity of the right ventricle to right atrium signal.

\section{STATISTICAL ANALYSIS}

All data are presented as means $\pm S D$. Data were recorded using a personal computer (Olivetti, Ivrea, Italy) and a database program (IBM Assistant, IBM Corporation, Armonk, New York, USA). Statistical analysis was performed using statistical software for biomedical science (Primer of Biostatistics, McGraw-Hill, New York, NY, USA). Baseline comparison among groups was performed using the Student's $t$ test and analysis of variance; linear regression and correlation were used to evaluate correlation between two variables; $p<0.05$ was considered significant.

\section{Results}

PATIENTS

The general characteristics of the patients with COPD are given in table 1 . As shown, the main biochemical parameters confirmed normal glucose and lipid metabolism and there was no evidence of abnormal renal function or of electrolyte disorders. Regarding respiratory parameters (table 2), patients with COPD were 


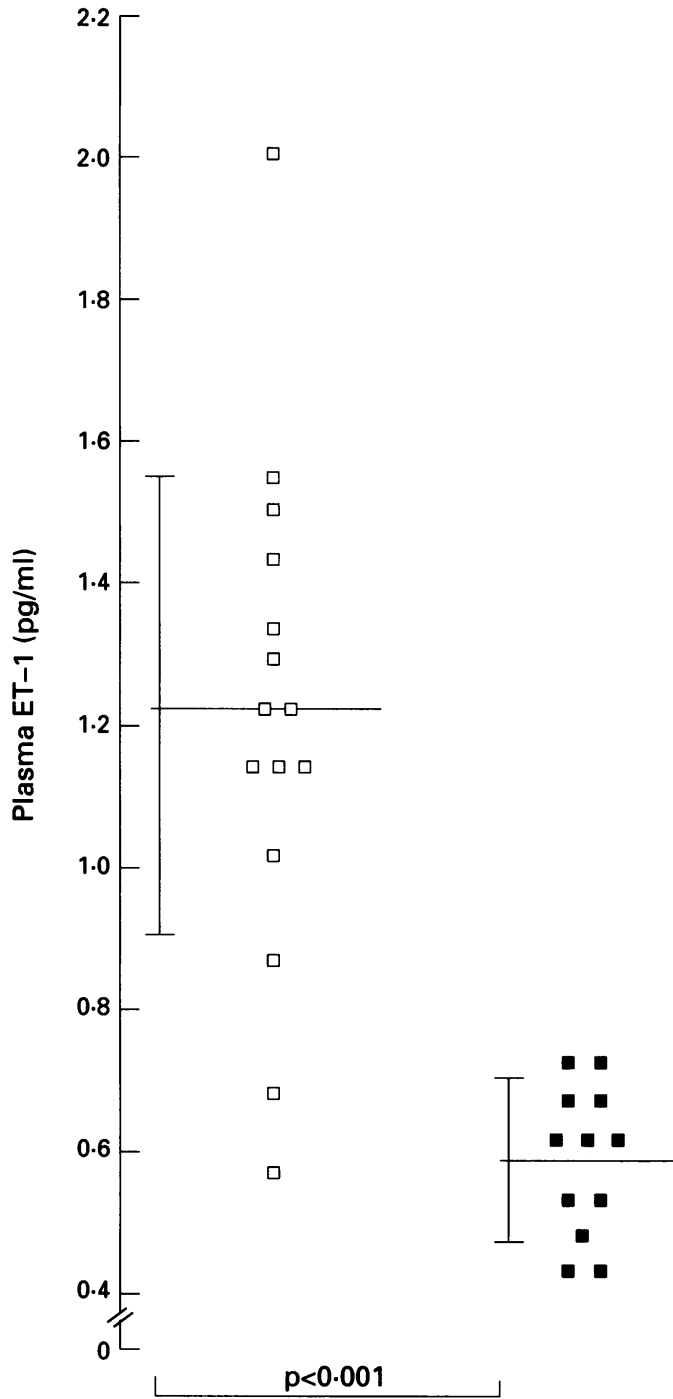

Figure 1 Scatterplots showing plasma endothelin-1 (ET1) concentrations in a group of hypoxaemic patients with COPD $(n=15 ; \square)$ and in a group of healthy subjects $(n=12 ; \square)$. Horizontal lines indicate the mean values; Vertical lines indicate the standard deviations.

characterised by reduced forced vital capacity $(2.8 \pm 1.5$ litres $)$ and $\mathrm{FEV}_{1}(1.9 \pm 0.21$ /one second). $\mathrm{PaO}_{2}$ values were within the normal range $(38 \cdot 1 \pm 2.5 \mathrm{mmHg})$. Arterial oxygen saturation

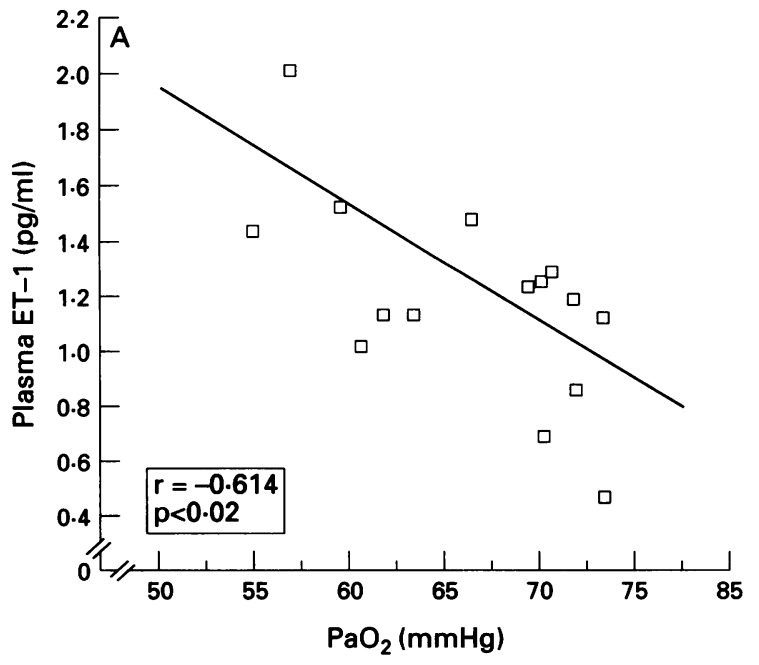

was $88 \cdot 5 \pm 4 \cdot 4 \%$ saturated haemoglobin. Echocardiographic evaluation did not show any segmental or global alterations in cardiac kinesis. Arterial pulmonary pressure was at the higher end of the normal range $(18.1 \pm 3.7 \mathrm{mmHg}$ ), the normal value at our echocardiography unit, as evaluated in 384 aged matched healthy subjects, being $10 \cdot 8 \pm 3 \cdot 1 \mathrm{mmHg}$ (range 8-24 mmHg). The left ventricular ejection fraction was slightly reduced $(65 \cdot 6 \pm 8 \cdot 9 \%)$, although it was greater than $50 \%$ in all patients. The mean circulating endothelin-1 concentration was $1 \cdot 22 \pm 0.36 \mathrm{pg} / \mathrm{ml}$ (fig 1 ). A negative correlation was found between plasma endothelin-1 concentrations and $\mathrm{PaO}_{2}(\mathrm{r}=$ $-0.614 ; \mathrm{p}<0.02$ ) (fig $2 \mathrm{~A}$ ). However, plasma endothelin-1 concentrations directly correlated with the degree of arterial pulmonary pressure $(r=0.571 ; p<0.03)$ (fig $2 B)$. It was also interesting to note that pulmonary pressure negatively correlated with $\mathrm{PaO}_{2}$ values $(\mathrm{r}=$ $-0.073 ; p<0.003)$. No other correlations were found. In particular, circulating endothelin-1 concentrations did not correlate with blood pressure, plasma glucose, or fasting insulin and lipid concentrations.

\section{CONTROLS}

The controls had normal values for glucose and lipid metabolism, and renal function (table 1). Cardiac and respiratory parameters (table 2) were also normal. In particular, the controls had normal arterial gas values $\left(\mathrm{PaO}_{2}=\right.$ $83 \cdot 8 \pm 2 \cdot 7 \mathrm{mmHg} ; \mathrm{PaCO}_{2}=36 \cdot 7 \pm 3 \cdot 1 \mathrm{mmHg}$ ) and oxygen saturation $(91 \cdot 3 \pm 3 \cdot 8 \%$ saturated haemoglobin). Plasma endothelin-1 concentrations were $0.57 \pm 0.10 \mathrm{pg} / \mathrm{ml}$ (fig 1) and did not correlate with $\mathrm{PaO}_{2}$. Arterial pulmonary pressure was $10.4 \pm 2.7 \mathrm{mmHg}$ and did not correlate with either circulating endothelin-1 concentrations or $\mathrm{PaO}_{2}$. Plasma endothelin-1 concentrations also did not correlate with the other parameters evaluated, such as plasma glucose and insulin concentrations.

\section{COMPARISON BETWEEN GROUPS}

When intergroup comparisons were performed, some significant differences were noted. Cir-

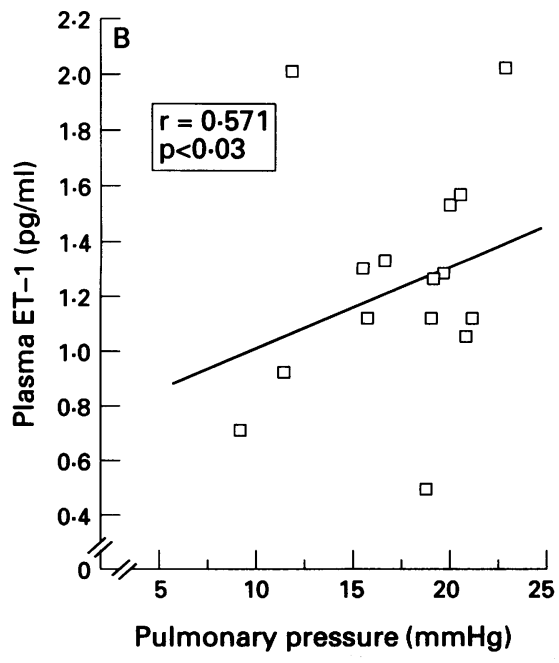

Figure 2 In patients with COPD ( $n=15)$ plasma endothelin-1 (ET-1) concentrations were negatively correlated with (A) arterial $\mathrm{PaO}_{2}$ but were directly correlated with $(B)$ arterial pulmonary pressure. 
culating endothelin-1 concentrations were significantly higher in patients with COPD than in controls $(p<0.001)$ (fig 1$)$, with very little overlap between the two groups. Indeed, in patients with COPD plasma endothelin-1 concentrations ranged from 0.54 to $2 \cdot 10 \mathrm{pg} / \mathrm{ml}$, whereas in controls these ranged from 0.42 to $0.72 \mathrm{pg} / \mathrm{ml}$ (fig 1). As a consequence, only two patients had plasma endothelin-1 concentrations within the normal range, whereas the remaining 13 had endothelin-1 concentrations two- to fourfold higher than those in controls.

As expected, both $\mathrm{FEV}_{1}$ and $\mathrm{FEV}_{1}$ /vital capacity were lower in the patients than controls $(\mathrm{p}<0.001$ and $\mathrm{p}<0.0005$, respectively) (table 2), as was $\mathrm{PaO}_{2}(\mathrm{p}<0.0005)$. Systolic, diastolic, and mean blood pressure values were similar in both groups (table 1); however, mean arterial pulmonary pressure was significantly higher in patients than in controls $(p<0.0001)$, but remained within the normal range in both groups. The left ventricular ejection fraction, however, was higher in controls $(\mathrm{p}<0.01)$ (table 2$)$.

\section{Discussion}

Endothelins are potent vasoconstrictors and mitogens for both vascular smooth muscle cells $^{1310}$ and fibroblasts. ${ }^{20}$ Increased secretion of endothelin-1 from the vascular endothelium has frequently been implicated in systemic hypertension, ${ }^{3}$ atherosclerosis, ${ }^{2}$ myocardial infarction, ${ }^{11}$ renal disease, ${ }^{310}$ and pulmonary hypertension. $^{12}$

Hypoxia causes both systemic and pulmonary arteries to constrict, ${ }^{21}$ but the mechanism involved has not been elucidated as yet. However, based on their location, endothelial cells of the vascular pulmonary bed are thought to play a key role. In keeping with this hypothesis, changes in blood oxygen tension induce endothelial cells to release a number of different vasoactive agents including endothelin-1, ${ }^{13}$ platelet derived growth factor, ${ }^{22}$ nitric oxide ${ }^{23}$ and other unknown substances, ${ }^{24}$ which can modify the contractile and proliferative state of the underlying smooth muscle cells.

All of the above data were obtained in acute conditions, and the aim of this study was to verify how long term low $\mathrm{PaO}_{2}$ values could affect circulating endothelin-1 concentrations. Thus, we selected a group of patients with mild COPD and to exclude confounding factors caused by advanced disease, the patients chosen were highly selected. Disease duration was less than five years in all cases and clinical and biochemical tests allowed us to exclude patients with signs of cor pulmonale, peripheral oedema, electrolyte disorders, or acid/base alterations. All patients were hypoxemic but had normal $\mathrm{PaCO}_{2}$ values. Furthermore, the study was conducted on lean normotensive subjects with no clinical or echo-Doppler signs of atherosclerosis, with normal blood pressure values, and normal carbohydrate and lipid metabolism.

Our results demonstrate that circulating endothelin-1 concentrations were significantly in- creased in hypoxemic patients compared with healthy subjects $(p<0.001)$. Moreover, endothelin-1 concentrations were negatively correlated with $\mathrm{PaO}_{2}$ and directly correlated with arterial pulmonary pressure. The latter was higher $(p<0.001)$ in hypoxemic patients than in the control subjects, being directly correlated with $\mathrm{PaO}_{2}$ in the former only.

Our results concur with previous findings in the rat, ${ }^{25}$ of increased synthesis of endothelin-1 in response to hypoxia. The intracellular pathway by which hypoxia modulates endothelin-1 synthesis in vascular endothelial cells is not known, but previous findings in cultured human endothelial cells suggested that oxygen may act at the nuclear level by increasing preproendothelin-1 gene expression and consequently preproendothelin-1 mRNA production. ${ }^{14}$ Action at the post-transcriptional level is unlikely as endothelin-1 release requires de novo protein synthesis. ${ }^{110}$

Our study extends the data reported by Giussani et al ${ }^{15}$ showing that chronic hypoxia is a major determinant of circulating endothelin-1 concentrations in patients with respiratory failure, and suggesting that it may be an important regulator of the vascular tone in the pulmonary circulation.

In this regard, hypoxia is already regarded as a possible pathogenic factor in the development of pulmonary hypertension, ${ }^{26}$ but the possible role of hypoxia mediated endothelin-1 release has never been investigated. However, Adnot et $a l^{23}$ have recently demonstrated that endothelin-1 induces greater pulmonary vasoconstriction in rats with chronic hypoxia compared with control rats. Moreover, Giaid et $a l^{27}$ reported elevated endothelin-1 gene expression in vascular endothelial cells derived from the lungs of patients with both primary and secondary forms of pulmonary hypertension. In keeping with these data, we showed that pulmonary pressure values were significantly correlated with plasma endothelin-1 concentrations, suggesting that the peptide may act as a potent vasoconstrictor for the lung vascular bed, at least in conditions associated with a significant increase in its circulating concentrations. In agreement with this interpretation, De Nucci $e t a l^{7}$ have already demonstrated the high avidity of the pulmonary vasculature for circulating endothelin-1, and both endothelial and vascular smooth muscle cells receptors ${ }^{28}$ have been demonstrated in the lung. In contrast to this hypothesis, Deleuze et $a l^{29}$ showed that endothelin-1 induced dose dependent vasodilation in the pulmonary circulation of calves breathing in hypoxic conditions. In particular, low doses of endothelin-1 induced a mild decrease in the pulmonary artery pressure, whereas high doses caused pulmonary vasodilation and systemic vasoconstriction. Thus, the action of endothelin-1 may differ in pulmonary and systemic circulations, refuting the suggested pathogenic role for endothelin-1 in the development of pulmonary hypertension. Nevertheless, the data from Deleuze et $a l^{29}$ may simply reflect the different pressures in the two vascular beds-the pulmonary circulation is a low pres- 
sure, low resistance vascular bed, where circulating endothelin-1 is cleared rapidly. ${ }^{7}$ Therefore, endothelin-1 could not constrict pulmonary vessels in vivo because of the presence of highly stimulated endothelin-B receptors on the luminal endothelial surface, ${ }^{1310}$ and the consequent endothelin-B receptor mediated release of prostacyclin and nitric oxide. ${ }^{7}$ Endothelin-1 does not readily penetrate the external endothelial cell membrane ${ }^{29}$ and therefore circulating endothelin-1 could not bind to endothelin-A receptors, which mediate vasoconstriction and are expressed by vascular smooth muscle cells lying beneath the endothelium. ${ }^{10}$ Therefore, it could be hypothesised that hypoxia might alter vascular reactivity to various agents, acting either in a paracrine or an autocrine manner and interacting at the vascular level. Locally, the prevalence of constrictor agents and/or a decrease in vasodilator concentrations could lead to the development of pulmonary hypertension. In this context, the increase in circulating endothelin-1 concentrations could reflect an increase in the intracellular production of endothelin-1 and its subsequent release. According to this hypothesis, about $80 \%$ of newly generated endothelin- 1 is secreted through the basolateral membrane, and only $20 \%$ is released into the blood. ${ }^{30}$ Perhaps, therefore, circulating endothelin-1 should be regarded as a marker for pulmonary hypertension rather than as a cause of lung disease.

In conclusion, the present study demonstrates for the first time that circulating endothelin-1 concentrations are increased in patients with chronic hypoxia. In spite of the increase in plasma endothelin-1 concentrations patients did not have concomitant systemic hypertension, renal damage, or cardiovascular disease. Thus, it is likely that endothelin-1, in conjunction with other endothelium derived vasoactive factors - for example, prostaglandin $\mathrm{I}_{2}$ and endothelium derived relaxing factor, acts in a autocrine/paracrine manner rather than in an endocrine one. The direct correlation between plasma endothelin-1 concentrations and pulmonary pressure values suggests that endothelin-1 may exert its vasoconstrictive action in the pulmonary vascular bed. Alternatively, it is possible that circulating endothelin-1 may have not a significant effect on the vascular tone in lung arteries, and may be a marker rather than a determinant of pulmonary disease associated with vasoconstriction.

1 Marsen PA, Brenner BM. Nitric oxide and endothelins: novel autocrine/paracrine regulators of the circulation. Semin Nephrol 1991;11:169-85.

2 Yanagisawa M, Kurihara H, Kimura S, Tomobe Y, Kobayashi M, Mitsui Y, et al. A novel potent vasoconstricto peptide produced by vascular endothelial cells. Nature peptide produced

3 Lüscher TF, Boulanger CM, Dohi Y, Yang Z. Endotheliumderived contracting factors. Hypertension 1992;19:117-30.

4 Schini V, Hendrickson H, Heublein D, Burnett J Jr, Vanhoutte P. Thrombin enhances the release of endothelin from cultured porcine aortic endothelial cells. Eur f Pharmacol 1989;165:333-4.
5 Yoshizumi M, Kurihara H, Morita T, Yamashita T, Ohhashi $\mathrm{Y}$, Sugiyama $\mathrm{T}$, et al. Interleukin-1 increases the production of endothelin-1 by cultured endothelial cells. Biochem Biophys Res Commun 1990;166:324-9.

6 Yoshizumi M, Kurihara H, Sugiyama T, Takaku F, Yanagisawa M, Masaky T, et al. Hemodynamic shear stress stimulates endothelin production by cultured endothelial cells. Biochem Biophys Res Commun 1989;161:859-64.

7 De Nucci G, Thomas R, D'Orleans-Juste P, Antunes E, Walder C, Warner TD, et al. Pressor effects of endothelin are limited by its removal from the pulmonary circulation and by release of prostacyclin and endothelium derived relaxing factor. Proc Natl Acad Sci USA 1988;85:9797-800.

8 Saijonmaa O, Ristimäki A, Fyhrquist F. Atrial natriuretic Saijonmaa $O$, Ristimäki $A$, Fyhrquist $F$. Atrial natriuretic
peptide, nitroglycerine, and nitroprusside reduce basal and stimulated endothelin production from cultured endothelial cells. Biochem Biophys Res Commun 1990;173: 514-20.

9 Cade C, Ilozue V, Rubanyi GM, Parker-Botelho LG. Smooth muscle cell factor responsible for decreasing big endothelin and endothelin produced by cultured endothelial cells. I Cardiovasc Pharmacol 1991;17(Suppl 7): 71-5.

10 Rubanyi GM, Parker Botelho LH. Endothelins. FASEB f 1991;5:2713-20.

11 Miyauchi $T$, Yanagisawa $M$, Tomizawa $T$, Sugishita $Y$, Suzuki N, Fujino M, et al. Increased plasma concentrations of endothelin-1 and big endothelin-1 in acute myocardial infarction [letter]. Lancet 1989;ii:53-4.

12 Stewart DJ, Levy R, Cernacek P, Langleben D. Increased plasma endothelin-1 in pulmonary hypertension-marker or mediator of disease? Ann Intern Med 1991;114:464-9.

13 Rakugi H, Tabuchi Y, Nakamaru M, Nagano M, Higashimori $\mathrm{K}$, Mikami $\mathrm{H}$, et al. Evidence of endothelin-1 release from resistance vessels of rats in response to hypoxia. Biochem Biophys Res Commun 1990;169:973-7.

14 Kourembanas S, Marsden PA, McQuillan LP, Faller DV. Hypoxia induces gene expression and secretion in cultured hypoxia induces gene expression and secretion in cul

15 Giussani M, Sala C, Cogo A, Ghio F, Pierini A, Legnani $\mathrm{D}$, et al. Effect of exposure to high altitude on plasma endothelin in man and its relationship with the changes in pulmonary and systemic pressures. Sixth European meeting on Hypertension; 1993 Jun 4-7; Milan.

16 De Angelis C, Farrace S, Urbani L, Ferri C, D'Amelio R, Santucci A, et al. Effects of high altitude exposure on plasma and urinary digoxin-like substance. Am $\mathcal{F}$ Hypertens 1992;5:600-7.

17 Lenz T, Scaley JE. Tissue renin system as a possible factor in hypertension. In: Laragh $\mathrm{JH}$, Brenner BM, eds. $H y$ pertension, pathophysiology, diagnosis and management. New pertension, pathophysiology, diagnosis

18 Wagner OF, Nowotny P, Vierhapper H, Waldhausl W. Plasma concentrations of endothelin in man: Arteriovenous differences and release during venous stasis. Eur $f$ Clin Invest 1990;20:502-5.

19 Hatle L, Brubakk A, Tromsdal A, Angelsen B. Noninvasive assessment of pressure drop in mitral stenosis by Doppler ultrasound. Br Heart $\mathcal{F}$ 1978;40:131-40.

20 Takuwa N, Takuwa Y, Yanagisawa M, Yamashita K, Masaki $T$. A novel vasoactive peptide endothelin stimulates mitogenesis through inositol lipid turnover in Swiss 3T3 fibrogenesis through inositol lipid turnover
blasts. $\mathcal{F}$ Biol Chem 1989;264:7856-61.

21 Holden WE, McCall E. Hypoxia-induced contractions of porcine pulmonary artery strips depend on intact endothelium. Exp Lung Res 1984;7:101-2.

22 Bowen-Pope DF, Hart CE, Seifert RA. Sera and conditioned media contain different isoforms of platelet-derived growth factor (PDGF) which bind different classes of PDGF receptors. $\mathcal{f}$ Biol Chem 1989;264:2502-8.

23 Adnot S, Raffestin B, Eddahibi S, Braquet P, Chabrier PE. Loss of endothelium-dependent relaxant activity in the pulmonary circulation of rats exposed to chronic hypoxia. $\Im$ Clin Invest 1991;87:155-62.

24 Vender RL, Clemmons DR, Kwock L, Friedman M. Reduced oxygen tension induces pulmonary endothelium to release a pulmonary smooth muscle cell mitogen(s). Am release a pulmonary smooth musc

$25 \mathrm{Li} \mathrm{H}$, Elton TS, Chen SJ, Durand J, Chen YF, Oparil S. Chronic hypoxia stimulates pulmonary endothelin-1 and endothelin receptor gene transcript levels in rats [abstract]. Circulation 1993;88:I-285.

26 Davies P, Maddalo P, Reid L. Effects of chronic hypoxia on structure and reactivity of rat lung microvessels. $\mathcal{f} \mathrm{Appl}$ Physiol 1985;58:795-801.

27 Giaid A, Yanagisawa M, Langleben D, Michel RP, Levy R, Shennib $\mathrm{H}$, et al. Expression of endothelin-1 in the lungs of patients with pulmonary hypertension. $N$ Engl f Med 1993;328:1732-9.

28 Hay DWP. Pharmacological evidence for distinct endothelin receptors in guinea-pig bronchus and aorta. Br $\mathcal{P}$ Pharmacol receptors in guinea-

29 Deleuze PH, Adnot S, Shiiya N, Thoraval R, Eddahibi S, Braquet $\mathrm{P}$, et al. Endothelin dilates bovine pulmonary Braquet $\mathrm{P}$, et al. Endothelin dilates bovine pulmonary circulation and reverses hypoxic pulmonary vaso-
constriction. $₹$ Cardiovasc Pharmacol 1992;19:354-60.

30 Wagner OF, Christ G, Wojta J, Vierhapper H, Panzer S, Nowotny PJ, et al. Polar secretion of endothelin-1 by cultured endothelial cells. $\mathcal{F}$ Biol Chem 1992;267:16066-8. 